University of Nebraska - Lincoln

DigitalCommons@University of Nebraska - Lincoln

Journal for the Advancement of Developing

Economies

Economics Department

2013

\title{
A Book Review of Capitalist Manifesto: Understanding the Market Economy and Defending Liberty
}

Brad Ward

Kellogg Community College, bnward@milligan.edu

Follow this and additional works at: https://digitalcommons.unl.edu/jade

Part of the Econometrics Commons, Growth and Development Commons, International Economics Commons, Political Economy Commons, Public Economics Commons, and the Regional Economics Commons

Ward, Brad, "A Book Review of Capitalist Manifesto: Understanding the Market Economy and Defending Liberty" (2013). Journal for the Advancement of Developing Economies. 20.

https://digitalcommons.unl.edu/jade/20

This Article is brought to you for free and open access by the Economics Department at DigitalCommons@University of Nebraska - Lincoln. It has been accepted for inclusion in Journal for the Advancement of Developing Economies by an authorized administrator of DigitalCommons@University of Nebraska - Lincoln. 


\title{
A Book Review of Capitalist Manifesto: Understanding the Market Economy and Defending Liberty
}

\author{
Brad Ward \\ Kellogg Community College
}

\begin{abstract}
The purpose of this paper is to review the book A Capitalist Manifesto: Understanding the Market Economy and Defending Liberty by Gary Wolfram. In a time of political unrest throughout the industrialized and developing world, Wolfram defends the free market economic system and educates the reader as to the various benefits of capitalism. According to the author, governments should create concise laws and regulations that allow individuals to pursue their ambitions without unnecessary interference. Wealth redistribution, a trait associated with socialism, leads to stagnant economies and minimal innovations. The roles that banks and the government play in the economy are discussed on a level beneficial to both the novice and skilled reader.
\end{abstract}

\section{BOOK REVIEW}

In the opening chapter of this timely volume, author Gary Wolfram argues that the anti-capitalist protests of the 21 st century are due to economic illiteracy. Terminology associated with capitalism, such as profitability, corporations, and executives are often correlated with greed, political power grabs, and inequality. Therefore, the Occupy Wall Street protestors are fighting greedy, politically manipulating corporations that extol the executive while crushing the proletariat. The author argues that the market system is responsible for creating the products that the protestors take for granted such as cell phones and automobiles.

So why is there such an economic gulf between the haves and have-nots? Human beings have always had an innate desire to specialize in certain professions including technology, trade goods or trade services. Consumers, who run the capitalist economic system, demand products that fulfill their daily wants and needs. The unequal distribution of wealth is then the result of consumer preferences for corporate products and cannot solely be blamed on capitalism. A Capitalist Manifesto: Understanding the Market Economy and Defending Liberty, attempts to educate the reader on basic economic principles and claims that societies around the world will be more prosperous if governments favor capitalism over socialism.

In the following four chapters, the market economy is explained in detail. In a short story that attempts to explain the market economy (supply and demand), Wolfram opens by describing a bus that cannot easily climb and navigate a hill if it is filled with passengers. The driver of the bus removes all passengers from the bus and forces each to buy his or her way back onto the bus.

To determine the price per ticket, buyers and sellers negotiate. Those who truly want a ride will pay more than those who do not. 
Another story mentions that, if humans are rational, they will proceed in an activity if the benefit outweighs the cost. Therefore, a thief may actually be acting rationally if he chooses to steal from his neighbor. If the unemployment rate in the area is high, and the cost of theft is a conviction that may lead to an unemployable condition, the robber may proceed with the robbery since the employment outlook is grim. The solution to this problem is to increase the chance of the robber finding meaningful employment and therefore, reducing the marginal benefit of his illegal action.

Now that the reader has a basic understanding of opportunity cost, supply, and demand, the author describes the process of creating the supply and demand curves, which leads to an understanding of market equilibrium. This section of the text is exceptional for those who are looking to review the graphing concepts from undergraduate microeconomic courses or those who simply are trying to understand basic economic theory. Conditions leading to shortages and surpluses are also graphically displayed in the text.

The book progresses to describe economic profit. For example, if an entrepreneur is going to open a business, she should first consider the opportunity cost of running the business verses profitability. In other words, if the entrepreneur could earn $\$ 100,000$ per year as an accountant, or she could earn $\$ 80,000$ per year from running a business, it may make more sense to become an accountant. In this case, the "true profit" of opening a business is $\$ 20,000$. Furthermore, the business owner in this example will also realize that, in the long term, new firms will adopt her production methods and compete against her, causing economic profits to decrease. If taxes are high in the entrepreneur's country she will have even less incentive to open her business. Consequentially, the chance of becoming wealthy would be stifled in a high tax environment, leading to few innovations and higher priced products.

In an extremely socialist country, a planner would make decisions as to what and how a product or service is produced. It is impossible for a planner to understand varying consumer demands and supply chain inventory systems; thus, the resources are allocated on a push system. A certain amount of products are produced, according to the planner, and demand may be less or more than the plan. Therefore, shortages (likely) or surpluses will exist in greater abundance than with a pull (market) system. The pull system describes the consumer demanding a product, and then competing companies create value and create a price that is acceptable to the consumer. Surpluses and shortages naturally adjust to consumer demand since organizations prefer to store an optimal amount of inventory.

So which political system is best? Wolfram argues that governments should create laws that protect life, liberty, and property, and that the laws should be easily understood (unlike the U.S. federal tax code). A government that promotes a free market economy, in the confines of a legal system that enforces contracts and creates laws that citizens may easily understand, is best since entrepreneurship and innovation are likely to flourish. When a government grows to disproportionate levels when compared to the private sector, wealth is coerced from successful citizens to assist those at the bottom of the financial pyramid. However, if the social strata are eliminated, philanthropy will decline since the government is ultimately responsible for helping the less fortunate. For example, if a high tax rate is imposed by the government, the wealthy have less incentive to support altruistic programs since they will expect the government to equalize the social classes. 
In the next section of the text, the author discusses the history of western economic progress. Beginning with medieval times, the feudal system, which foreshadows socialism, consisted of serfs and lords. The lowly serfs worked towards a common good by crossing property lines to plant and harvest crops. The lords, on the other hand, dictated the quantity of production. The farms were self-sufficient and trade was minimal. In addition, the guilds forced skilled laborers to confer with "union" leadership before any improvements to processes could be implemented. Although the pace of innovation was slow, inventions such as the compass, navigational equipment, and movable type made it possible for commerce to expand.

Following the expansion of trade, the author discusses an alternate view of the industrial revolution. The predominant view is that the revolutionary period was a time of management domination over their expendable workforce. Wolfram, conversely, argues that the factory system created a higher standard of living for men, women, and children than agrarian or artisan life. The U.S. government at this time was laissez-faire; a system that produced an environment that allowed business owners to hire and create working conditions as they saw fit. From the perspective of a modern American, wages were extremely low, workers' rights were violated, and working conditions were unsafe. However, the supply of goods and services increased, and the poor could afford goods that were previously out of reach. From 1914 onward, increasing amounts of business legislation led to an explosion in the amount of government employees required to oversee business/employee relationships. For example, spending by the federal government, as a percentage of national income, was 2.5 percent in the early 1900s when compared to 25 percent today.

So what lessons have we learned from history? According to Wolfram, centrally planned economies will not be able to compete with governments that are free market promoters. After World War I, and especially following the Great Depression, U.S. citizens became reliant on the government to intervene during wartime and recessionary periods. Although this mindset permeates modern America, free market advocates such as Rush Limbaugh, the CATO Institute, and the Heritage Foundation are growing in popularity.

To conclude his book, Wolfram discusses the role of government in terms of macroeconomic theory. Major financial indicators such as the Consumer's Price Index and Gross Domestic Product are discussed. The role of the Federal Reserve and the U.S. Government are additionally addressed. Keynesian economic theory is briefly described: to reduce unemployment, aggregate demand must be increased. To do so, the government intervenes by creating government jobs(increasing employment) and reducing taxes. The inverse is implemented to slow down the economy. Also, the money supply may be adjusted through the banking system to either slow down or speed up economic progress.

As the title implies, A Capitalist Manifesto: Understanding the Market Economy and Defending Liberty does just that: educates the general public as to the various benefits of a free market economy. The author does an exceptional job, especially to the layman, covering basic micro and macro-economic theory in a manner that is educational and enlightening. However, the book does have two limitations. First, from an historical perspective, the negative results of free market policies are overlooked. For instance, the Dutch East India Trading Company (VOC), an example utilized to demonstrate the benefits of free market economies, was able to monopolize with the help 
of the Dutch government. Trade routes were in high demand and the Portuguese blocked Dutch merchants from navigating around the coast Africa. The Dutch government, then, intervened and assisted the traders via military protection (Vergne, 2008). Slave trading was also utilized by the VOC (Welie, 2008). In regards to the industrial revolution, it was a time of unsafe and dehumanizing working conditions. U.S. companies such as the Ford Motor Company minimized the skills needed to perform tasks and treated their workers as parts of the "machine." Regardless of Ford's unprecedented $\$ 5$ per day wage, unions were eventually able to infiltrate the automotive industry (Raff \& Summers, 1987). Furthermore, in organizational theory, the human relations movement follows the industrial revolution since workers were finally considered to be a valuable asset to businesses.

Second, in a purely free market economy, businesses will not always promote socially responsible initiatives. For example, pharmaceutical companies may not pursue researching and developing medication aimed at eradicating diseases that affect a minute proportion of society. The free market will not simply create products for philanthropic purposes. Wolfram does claim that an increase in social programs will decrease an individual's incentive to give, but businesses operating in the free market are pursuing profits, not societal improvements.

Moving forward, economic education is imperative for any concerned citizen. Wolfram does an exceptional job explaining the wonders of the free market system. Legislation should be simplified in order to grant individuals the liberty necessary to form and sustain their businesses. Creating a society of "equals" will stifle innovation and result in a feudal-like economy. Planned economies seldom excel and allocating resources from a central agency is ineffective and unsustainable. Although a free market system is not without problems, there is no better system in which individuals can economically flourish.

\section{REFERENCES}

Raff, D. G., \& Summers, L. H. (1987). Did Henry Ford pay efficiency wages?. Journal of Labor Economics, 5(4), 57-86.

Vergne, J. (2008). The social construction of competitive advantage and the origin of global capitalism: The case of the Dutch East India Company. Academy of Management Annual Meeting Proceedings, 1- 6. doi:10.5465/AMBPP.2008.42749128

Wolfram, G. (2012). A capitalist manifesto: Understanding the market economy and defending liberty. USA: Dunlap Goddard 